\title{
Capture and Release: The Story of the Russian Military Topographic Map Collection
}

The map collection of the Herman B. Wells Library at Indiana University (IU) Bloomington contains approximately 400,000 sheet maps covering nearly every country in the world. While the state of Indiana is a major focus of the collection, it also has strengths in Eastern Europe and Central Asia. In particular, the Russian Military Topographic Map Collection is of great value to IU's reputable Russian and East European Institute, and its Central Eurasian Studies program. As a result, the IU Libraries were awarded a Council of Information and Library Resources (CLIR) Hidden Collections grant in 2018 to fund the digitization of this collection.

The Russian Military Topographic Map Collection (go. iu.edu/2aJ4) contains over 4,000 maps depicting Eastern Europe, western Russia, and the Caucasus at scales of 1:25,000, 1:50,000, and 1:100,000. These maps were made by the Russian military for internal strategizing and tactical use in the field, and were considered top secret. The maps were published between 1883 and 1947 by a variety of agencies, including the Main Geodesic Department (Главное геодезическое управление), the General Headquarters of the Red Army (Генеральный штаб Красной Армии), and the Military Topographical Management (Военно-Топографическое Управление). While Soviet military topographic maps from the Cold War era are abundant, it is rare to find pre-World War II maps of this area at such detailed scales (see Figure 1). As Alexander Kent, author of The Red Atlas: How the Soviet Union Secretly Mapped the World, noted in his letter of support for the digitization project:

The period in their collection ranges from Tsarist Russia through the birth of the Soviet Union and Stalin's decree to map the world. Of especial interest is the large-scale pre-war mapping of the Soviet borderlands, which is very rare indeed. Topographic maps were considered secret documents in the Soviet Union and large-scale maps of the era are scarce; exporting topographic maps of Russian territory at scales larger than 1:200,000 is still prohibited in that country.

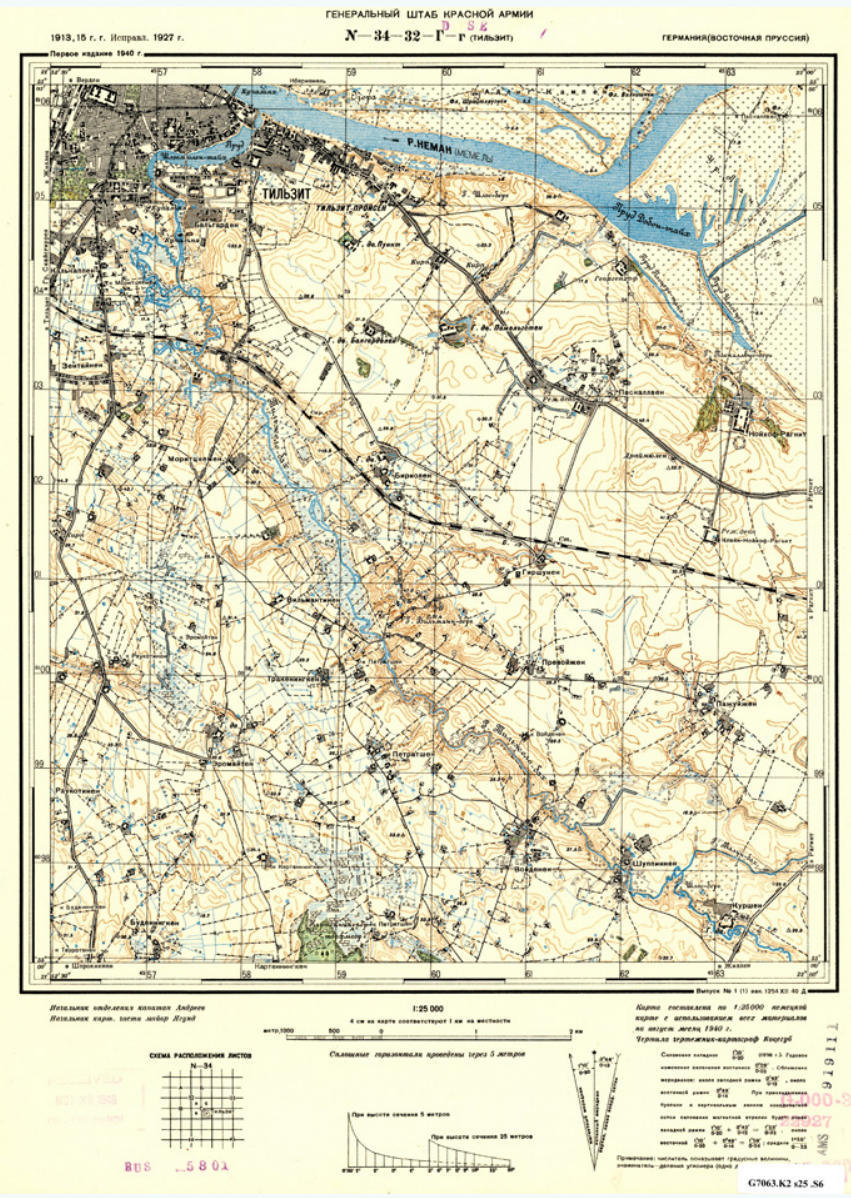

Figure 1. 1:25,000 large-scale map of Tilsit, East Prussia, Germany (now Sovetsk, Kaliningrad Oblast, Russia). Individual buildings can be clearly seen. purl.dlib.indiana.edu/iud1/images/ VAC9619/VAC9619-003613. 
In the years surrounding World War II, many of these maps were captured in the field by opposing forces, including German and American troops. After capture, the maps were stamped with the names of the various organizations that received them, such as the University of Berlin, the US Army Map Service, and the Central Intelligence Agency Map Library (see Figures 2-5). Some maps are marked "Секретно" (Secret) and others bear stamps from Nazi German institutions with swastika insignias. These myriad stamps offer a unique visual history, allowing us to trace the how these maps traveled from Russian troops in the field to Bloomington, Indiana.

After the war, the maps were eventually sent to the Library of Congress. Indiana University's collection was established from a cataloging exchange arrangement with the Library of Congress. IU Map Librarian Dan Seldin, participated in the Geography and Map Division Special Project in the late 1990s. This was a summer internship program, in which map librarians and catalogers would spend a summer processing and cataloging maps at the Library of Congress's Geography and Map Division (loc. gov/loc/lcib/0109/intern.html). In exchange, the interns would be invited to select duplicate maps from the Library of Congress collection to take back to their home institutions. Seldin chose the Russian military maps to complement IU's academic and disciplinary strengths.

\section{ONLINE ACCESS TO THE COLLECTION}

The Russian Military Maps project was funded in 2018 by CLIR as part of its "Digitizing Hidden Special Collections and Archives" program, which is designed to enable new scholarship by improving access to unique materials, and is supported by The Andrew W. Mellon Foundation. As part of the grant, the collection is being digitized, fully described, georeferenced, and made publicly available through the IU Libraries' Image Collections Online (ICO), a repository service for the preservation and publication of digital image collections curated by IU and affiliated cultural heritage institutions. ICO provides collections managers with the ability to showcase image collections using a standards-based cataloging tool and web publishing mechanism.

As part of the digitization process, we are creating detailed descriptive metadata for each map. Metadata includes typical fields such as publisher and date, and also provenance information created by transcribing the stamps on the

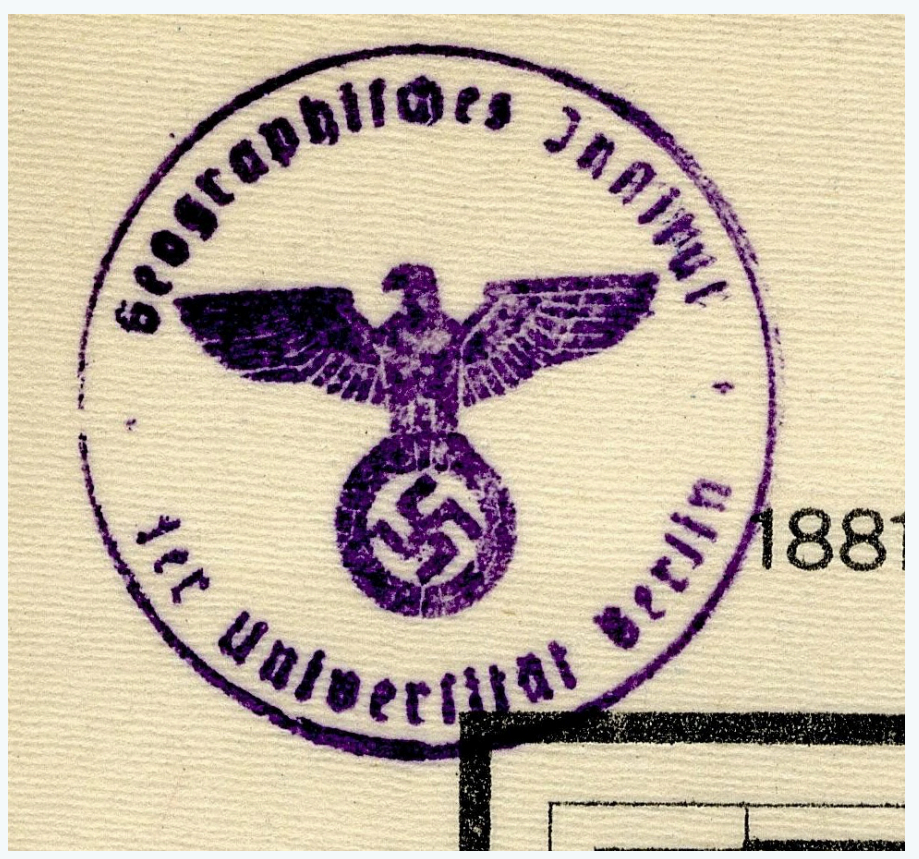

Figure 2. Stamp from Geographisches Institut der Universität Berlin on a map of Łomazy, Poland. purl.dlib.indiana.edu/iudl/ images/VAC9619/VAC9619-002739.

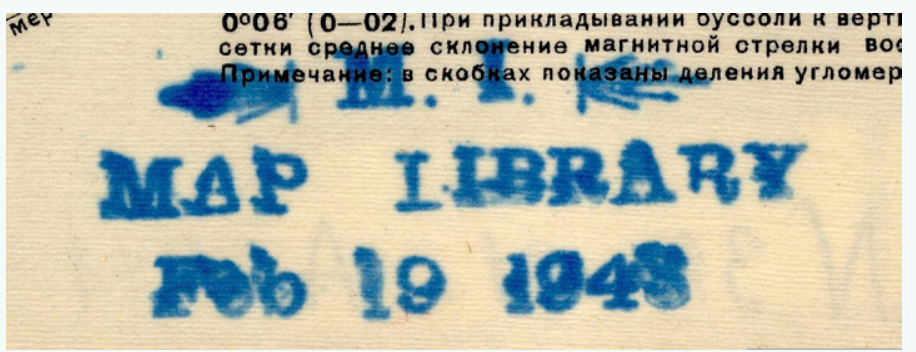

Figure 3. "M. I. Map Library" stamp on a map of Nida, Lithuania. purl.dlib.indiana.edu/iudl/images/VAC9619/VAC9619-000275.

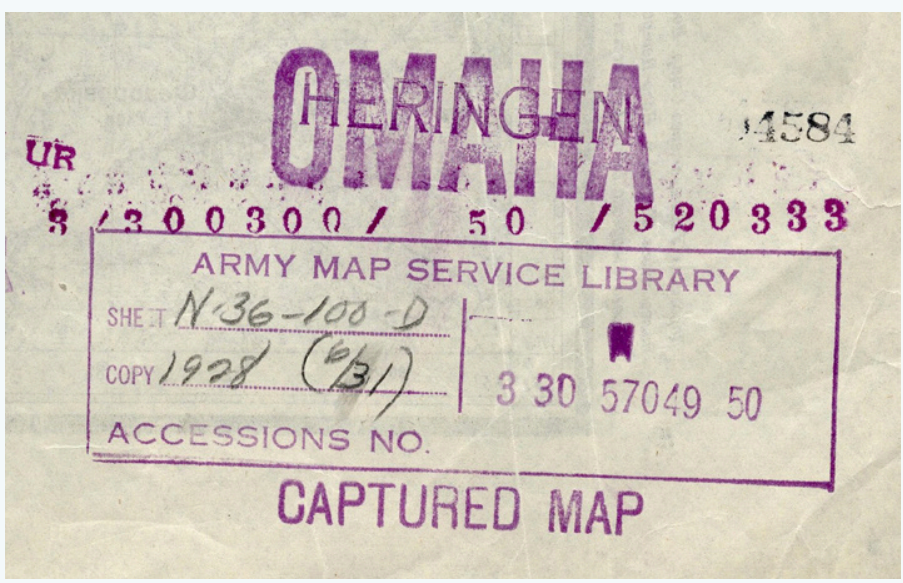

Figure 4. Army Map Service Library stamp on a 1928 map of Antonovka, Belarus. Also stamped "Captured Map." purl.dlib. indiana.edu/iudl/images/VAC9619/VAC9619-001496. 

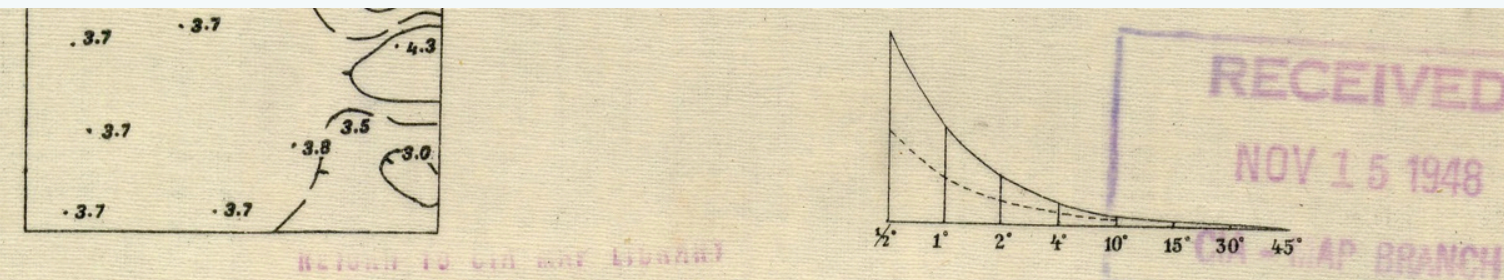

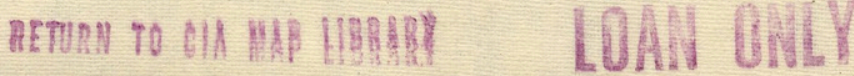

Figure 5. CIA Map Library Stamps on a map of Orlino, Russia. purl.dlib.indiana.edu/iud1/images/VAC9619/VAC9619-003312.

maps. In addition, our metadata specialists provide metadata in the original Russian as well as English, allowing researchers to search in either language. These maps cover a part of the world that has seen dramatic shifts in political boundaries since their creation. To aid in discovery, both historic and contemporary place names are included in the metadata, allowing us to describe maps of Belarus that cover areas that are now in modern day Poland, for example.

\section{RESEARCH IMPACT}

Changes in political boundaries, war, forced resettlement, and demographic shifts permanently changed Eastern Europe. These maps provide scholars with a unique historical view of the pre-World War II landscape. Given that the geographic area covered by these maps would later become part of the Soviet sphere of influence, the existence of these maps provides evidence of intentional action, or, at the very least, special interest on the part of the Soviets in this borderland region.

We have documented nearly 80 reference emails since the initial maps were published in 2014. To date, the questions we have logged reveal that researchers have been interested in locating historical places no longer in existence (or whose names have since changed), in combat strategies, and in remote sensing. By and large, those who specified their research interests were investigating lost settlements. Others have indicated interest in historically-based research on military or combat strategies and how those strategies are revealed in these maps. As we increasingly make maps from this collection available online, we will continue to track reference and research inquiries to have a better understanding of how these maps are being used in historical, socio-cultural, and military scholarship.

\section{FUTURE PLANS}

While the project's enhanced metadata greatly increases discoverability of these maps, we also wanted to create a geographic finding aid. As part of the grant project, GIS specialists are georeferencing each of the 4,000 maps and creating GeoTIFFs both with and without the map collars. Future plans for the project include creating an interactive index map that links to individual map records in ICO, as well as download links to the GeoTIFFs. We will contribute this index map to the "Clearinghouse of Indexes to Paper Map Sets," maintained by Chris Thiry at the Colorado School of the Mines (bit.ly/33Awsiy). In addition, the project GIS Specialists are in the process of creating country-level raster mosaics in areas where we have contiguous coverage. These raster mosaics will eventually be hosted to provide users with a Web Map Tile Service (WMTS) that can be used in web maps and GIS as baselayers.

Intriguing as it is to trace the journey of these captured maps over time, it does not bring us much closer to understanding the set as a whole. Since these maps were dispersed by warring interests, a complete collection is not likely to exist. However, once the Russian Military Maps index is completed, it will help us, and/or researchers, identify areas that are missing in Indiana University Libraries' collection. Other institutions who hold maps like these could use the index to prioritize digitization and online access for those parts of their collection that could complete the story. 